\title{
PENERAPAN STRATEGI DICTOGLOS UNTUK MENINGKATKAN KEMAMPUAN MENCERITAKAN KEMBALI PERISTIWA SEJARAH
}

\author{
Adhita Dwi Handayani \\ Universitas Islam Darul Ulum Lamongan \\ adhitadwi1@gmail.com
}

\begin{abstract}
Abstrak : Latar belakang penelitian ini berawal dari sebuah proses pembelajaran yang dilakukan oleh guru yang mengajar di kelas tinggi. Dalam proses pembelajarannya tersebut guru jarang menggunakan media pembelajaran dan strategi pembelajaran yang unik untuk menunjang proses pembelajarannya. Cara yang digunakan guru dalam proses pembelajaran adalah dengan metode ceramah saja, sehingga cara guru mengajar membuat siswa mengalami kebosanan, bicara sendiri, mengantuk, bercerita dengan teman sebangkunya, dan siswa tidak tertarik dengan pembelajaran tersebut. Apalagi mata pembelajaran pada saat itu adalah tentang sejarah Indonesia. Pada akhirnya banyak siswa yang tidak dapat menerima konsep pembelajaran pada hari itu. Sedangkan dalam kurikulum 2013 siswa dituntut untuk berfikir kreatif, aktif dan produktif serta siswa terlibat langsung dengan proses pembelajaran. Hal ini mengakibatkan penurunan siswa dalam pemahaman akan materi tentang sejarah, maka perlu adanya pemecahan masalah yaitu penggunaan strategi dictoglos. Tujuan peneliti ini untuk mengkaji aktivitas guru dan siswa selama proses pembelajaran dengan menggunakan strategi dictoglos. Dengan menggunakan strategi dictoglos siswa lebih senang dan antusias dalam proses pembelajaran. Penelitian ini menggunakan Penelitian Tindakan Kelas.
\end{abstract}

Kata kunci : strategi, sejarah, kemampuan bercerita

\section{A. PENDAhuluan}

Bangsa yang besar adalah bangsa yang menghargai sejarah bangsanya. Menghargai sejarah merupakan suatu konsep yang harus dimiliki oleh setiap siswa. Dengan demikian konsep ini harus dikembangkan dan diupayakan penerapannya.

Sejarah bukan sekedar kejadian di masa lampau, tetapi pemahaman masa lampau yang di dalamnya mengandung berbagai dinamika, mungkin juga berisi problematika pelajaran bagi manusia berikutnya Moh. Hatta: 1951. Dikatakan demikian karena melalui sejarah kita tidak hanya sekedar mengetahui peristiwa yang terjadi pada masa lampau, tetapi juga kita dapat mengambil nilai-nilai positif berdasarkan pengalaman seseorang pada masa lampau yang bisa kita jadikan pembelajaran dalam kehidupan kita nantinya.

Berdasarkan pernyataan Moh. Hatta tersebut maka seorang siswa harus memiliki sikap menghargai sejarah. Penanaman konsep mengenai sikap menghargai sejarah dapat dilakukan dalam pembelajaran sejarah di sekolah. Konsep menghargai sejarah meliputi 
menghargai berbagai peninggalan serta tokoh sejarah. Karena melalui sejarah pula siswa dapat memetik nila-nilai positif berdasarkan peristiwa yang terjadi pada masa lampau.

Di Indonesia, ilmu sejarah telah menjadi salah satu mata pelajaran wajib dalam kurikulum, sejak sekolah dasar. Pembelajaran sejarah yang diberikan di sekolah bukan hanya sekedar untuk mendapatkan nilai, tetapi juga pembelajaran sejarah secara formal tersebut memiliki arti yang luas dan mendalam. Dalam kehidupan masyarakat, sejarah memiliki arti dan peran yang penting karena dengan belajar sejarah akan menjadikan siswa memiliki sikap bijaksana, berwawasan luas, memiliki semangat patriotisme dan nasionalisme yang tinggi. Maka dari itu pelajaran sejarah perlu diberikan kepada anak sejak usia dini.

Namun pada kenyataannya sekarang ini, minat siswa akan sejarah semakin hari semakin menurun. Kebanyakan dari mereka tidak tertarik dengan pelajaran yang banyak membacanya khususnya sejarah. Karena siswa pada tingkat sekolah dasar akan mengalami banyak kesulitan dalam menghafal tanggal beserta peristiwa yang terjadi di masa lampau. Hal ini tentunya akan menghambat penanaman konsep mengenai pentingnya mempelajari sejarah. Selain itu juga metode pembelajaran yang digunakan guru dirasa kurang menarik sehingga membuat siswa sulit untuk dapat menerima materi. Keadaan ini memang menjadi hal yang memprihatinkan. Siswa memandang sejarah hanya sebagai materi pelengkap pembelajaran, bukan sebagai pelajaran pokok yang merupakan bentuk apresiasi nasionalisme dan bukti cinta tanah air.

Menurut Cronbach, "Learning is shown by change in behavior as result of experience", yang artinya belajar yang terbaik adalah melalui pengalaman. Dengan pengalamanan tersebut siswa akan menggunakan seluruh pancaindranya. Pendapat ini didukung ole Spears (1955), yang menyatakan bahwa "Learning is to observe, to read, to imitate, to try something themselves, to listen, to follow direction", yang artinya adalah belajar merupakan kegiatan mengamati, membaca, mencontoh, mencoba sesuatu, mendengarkan, mengikuti perintah. Berdasarkan teori-teori yang dijelaskan di atas maka dalam kegiatan pembelajaran siswa tidak diperkenankan bersifat pasif dalam kegiatan pembelajaran.

Melihat permasalahan yang muncul, dapat disimpulkan bahwa permasalahan lebih banyak disebabkan oleh pendekatan dan strategi yang digunakan oleh guru dalam mengajarkan materi mengenai peristiwa sejarah. Hal tersebut ditunjukkan bahwa dalam pembelajaran kurang adanya interaksi antara guru dengan siswa, sehingga siswa akan merasa jenuh. 
Atas dasar hal tersebut, maka peneliti berasumsi bahwa pendekatan dan strategi yang digunakan oleh guru kurang tepat. Oleh sebab itu peneliti mencoba menawarkan sebuah strategi yang diharapkan dapat membantu guru dan siswa untuk meningkatkan kualitas pembelajaran tentang menceritakan kembali peristiwa sejarah. Strategi yang dimaksud adalah menceritakan kembali peristiwa sejarah melalui strategi dictoglos. Bentuk kegiatannya adalah berupa penelitian tindakan kelas yang dilaksanakan oleh peneliti berkolaborasi dengan guru kelas V MI Ma'arif NU Sukolilo

Oleh sebab itu, peneliti tertarik untuk berkolaborasi dengan guru kelas V MI Ma'arif NU Sukolilo untuk melaksanakan penelitian tindakan kelas. Penelitian dilakukan sebagai upaya untuk meningkatkan kemampuan menceritakan kembali peristiwa sejarah bagi siswa kelas V MI Ma'arif NU Sukolilo. Adapun tindakan yang dilakukan adalah meningkatkan kemampuan menceritakan peristiwa sejarah melalui strategi dictoglos.

Berdasarkan hal diatas maka penulis tertarik untuk mengangkat judul penelitian: "PENERAPAN STRATEGI DICTOGLOS UNTUK MENINGKATKAN KEMAMPUAN MENCERITAKAN KEMBALI PERISTIWA SEJARAH BAGI SISWA KELAS V MI MA'ARIF NU SUKOLILO”.

\section{B. KAJIAN TEORI}

\section{1) Hakikat Pembelajaran IPS di SD}

Pembelajaran merupakan kegiatan belajar mengajar ditinjau dari sudut kegiatan siswa, berupa pengalaman belajar siswa yaitu kegiatan siswa yang direncanakan guru untuk dialami siswa selama kegiatan belajar mengajar (Mulyati :2000). ${ }^{1}$

Menurut Nasution, IPS merupakan fungsi dari sejumlah ilmu-ilmu sosial yang disederhanakan untuk tingkat dasar. Sedangkan berdasarkan KTSP, IPS adalah mata pelajaran yang mengkaji seluruh peristiwa, fakta, konsep dan generalisasi yang berkaitan dengan sosiologi, ekonomi, sejarah dan geografi.

Dengan demikian dapat dikatakan bahwa pelajaran IPS merupakan mata pelajaran yang mengkaji ilmu-ilmu sosial, yang meliputi materi mengenai fakta, konsep dan generalisasi.

\footnotetext{
${ }^{1}$ Mulyati, Strategi belajar mengajar IPS (Raja Grafindo Persada: 2000).
} 
Sedangkan mengenai pembelajaran IPS di SD dapat dikatakan bahwa mata pelajaran IPS merupakan mata pelajaran yang mengkaji seluruh ilmu-ilmu sosial yang digunakan untuk mendidik siswa menjadi makhluk sosial yang berkarakter. Hal ini didukung oleh pernyataan Waspodo bahwa IPS adalah pendidikan ilmu-ilmu sosial yang diintegrasikan dan disederhanakan untuk membina siswa menjadi warga Negara yang baik.

Sejak bidang studi IPS masuk dalam Kurikulm Pendidikan tahun 1975 hingga sekarang, keberadaan ilmu-ilmu sosial selalu menjadi bagian yang tidak terpisahkan dari materi pembelajaran IPS.

Keberadaan IPS sebagai sebuah bidang studi memang dibangun dari berbagai konsep, fakta, dan generalisasi. IPS merupakan pengetahuan sosial terapan sehingga menjadi kewajiban bagi ilmu-ilmu sosial untuk selalu mengembangkan dan menyederhanakan materi tersebut ke dalam bahan pembelajaran di sekolah. Disiplin ilmu-ilmu sosial terdiri dari geografi, sejarah, ilmu ekonomi, ilmu politik, sosiologi dan antropologi. Namun pada pembelajaran di MI hanya meliputi geografi, sejarah dan ekonomi saja, itu pun masih dalam tahap dasar, yaitu tahap penanaman konsep.

Mempelajari pengetahuan dasar ilmu-ilmu sosial sama artinya dengan mempelajari landasan berpikir utama dari ilmu-ilmu sosial, karena akan menyangkut tentang ruang lingkup, pengertian obyek, kajian, pendekatan dan konsep-konsep dasar ilmu-ilmu sosial serta tokoh-tokoh yang paling berpengaruh dalam pengembangan masing-masing disiplin ilmu sosial, maka dari itu diperlukan mata pelajaran IPS di SD.

Ruang lingkup mata pelajaran IPS di SD meliputi aspek-aspek sebagai berikut: (a)Manusia, tempat dan lingkungan; (b)Waktu, keberlanjutan dan perubahan; (c)Sistem sosial dan budaya; (d) Perilaku ekonomi dan kesejahteraan (Sardiyo: 2008) ${ }^{2}$

Kajian yang Dipelajari dalam IPS adalah (1) Sosiologi mempelajari segala hal yang berhubungan dengan aspek hubungan sosial yang meliputi proses, faktor, perkembangan, permasalahan dan lain lain; (2) Ilmu ekonomi mempelajari proses, faktor, perkembangan, permasalahan yang berhubungan dengan ekonomi; (3) Segala aspek psikologi yang berhubungan dengan sosial dipelajari dalam ilmu psikologi social; (4) Aspek budaya perkembangan dan permasalahannya dipelajari dalam antropologi; (5) Aspek sejarah yang tak dapat dipisahkan dalam kehidupan kita dipelajari dalam sejarah; (6) Aspek geografi yang memberi efek ruang terhadap kehidupan manusia dipelajari dalam geografi; (7) Aspek politik yang menjadi landasan keutuhan dan kesejahteraan masyarakat dipelajari dalam ilmu politik.

\footnotetext{
${ }^{2}$ Sardiyo, Pendidikan IPS di SD (Jakarta, Universitas Terbuka: 2008). Hal 54
} 
Norma, nilai bahasa, seni dan sebagainya yang menjadi komponen dalam kehidupan manusia dipelajari dalam bidang humaniora, walau humaniora dan ilmu sosial berbeda namun mengkaji objek yang sama sehingga IPS mengintegrasikan keduanya. Karena itu, IPS merupakan mata pelajaran yang mempelajari kehidupan sosial yang kajiannya mengintegrasikan bidang-bidang ilmu sosial dan humaniora.

Berdasarkan keterangan di atas dapat disimpulkan bahwa seorang anak sangat memerlukan pendidikan IPS dikarenakan pengetahuan sosial sangat diperlukan dalam kehidupan sehari-hari. Meskipun pengetahuan sosial dapat diperoleh secara alamiah dalam kehidupan sehari-hari, namun hal ini dirasa belum cukup mengingat kehidupan masyarakat dengan permasalahan yang semakin berkembang, maka dari itu dalam kenyataannya untuk menghadapi hal demikian diperlukan pendidikan formal, khususnya pendidikan IPS.

Pembelajaran IPS lebih menekankan pada keterampilan proses dalam pencapaian hasil belajar. Ditinjau dari tujuan institusional pendidikan dasar, pembelajaran IPS memiliki beberapa tujuan khusus, antara lain: (a) Membekali anak didik dengan kemampuan ilmu dan pengetahuan dasar untuk melanjutkan pendidikan ketingkat yang lebih tinggi; (b) Membekali anak didik dengan pengetahuan sosial yang berguna dalam kehidupan di masyarakat; (c) Membekali anak didik dengan kemampuan mengidentifikasi, menganalisis, dan menyusun alternatif pemecahan masalah sosial yang terjadi dalam kehidupan di masyarakat; (d) Membekali anak didik dengan kemampuan berkomunikasi dengan sesama warga masyarakat dan dengan berbagai bidang keilmuan serta berbagai keahlian; (e) Membekali anak didik dengan kesadaran, sikap mental yang positif, dan keterampilan terhadap lingkungan hidup yang menjadi bagian dari kehidupannya yang tidak terpisahkan; (f) Membekali anak didik dengan kemampuan mengembangkan pengetahuan dan keilmuan IPS sesuai dengan perkembangan kehidupan, perkembangan masyarakat, perkembangan ilmu, dan teknologi. (Nursid Sumaatmadja, 2008: 48 ). $^{3}$

Berdasarkan uraian tujuan pembelajaran IPS menurut Nursid, dapat disimpulkan bahwa pembelajaran IPS bertujuan untuk mengembangkan pribadi siswa agar menjadi individu yang baik dengan cara menerapkan pengetahuan, nilai, sikap, dan kemampuan yang diperoleh pada pembelajaran IPS.

\footnotetext{
${ }^{3}$ Sumaatmadja, Materi Konsep Dasar IPS (Karunika Universitas Terbuka: 2008). Hal 48
} 
Strategi dictoglos merupakan salah satu strategi dalam pembelajaran menyimak. Dalam strategi ini guru membacakan sebuah wacana singkat kepada siswa dengan kecepatan normal dan siswa diminta menuliskan kata sebanyak yang mereka mampu. Kemudian siswa bertugas untuk merekonstruksi wacana dengan mendasarkan kepada serpihan-serpihan yang telah mereka tulis. Strategi ini mirip dengan metode dikte tradisional.

Pada strategi dictoglos, siswa akan mengintegrasikan pengetahuan "dalam kepala" atau background knowledge mereka. Melalui strategi dictoglos ini, siswa akan mampu: (1) membuat prediksi-prediksi; (2) membuat inferensi-inferensi tentang hal-hal yang tidak ada di dalam teks; (3) mengenali topik teks; (4) mengenali jenis teks (apakah naratif, deskriptif, anekdot, dan sebagainya); dan (5) mengenali berbagai jenis hubungan semantik di dalam teks.

Dengan demikian, strategi dictoglos mampu memanfaatkan prinsip bahwa dua kepala selalu lebih baik daripada satu kepala. Siswa mampu mengumpulkan dan memanfaatkan sumber-sumber, bahkan untuk siswa yang tergolong low-level. Dengan bekerja sama, siswa akan mampu melakukan sesuatu di atas kompetensi mereka yang sebenarnya.

Ada empat tahap dalam strategi dictoglos, antara lain:

a) Persiapan

Pada tahap ini, guru mempersiapkan siswa untuk siap dalam menyimak teks yang akan mereka dengar dengan cara mengajukan pertanyaan-pertanyaan dan mendiskusikan gambar stimulus.

b) Dikte

Siswa mendengarkan dikte dua kali. Pertama, mereka hanya mendengar dan mendapatkan gambaran umum teks tersebut. Kedua, mereka membuat catatan, dengan dimotivasi hanya untuk mencatat kata-kata isi yang nantinya akan membantu mereka merekonstruksi teks.

c) Rekonstruksi.

Pada akhir dikte, siswa mengumpulkan catatan-catatan dan menyusun kembali teks versi mereka. Selama tahap ini perlu diingat bahwa guru tidak memberikan masukan bahasa kepada siswa. Pada tahap rekonstruksi ini, siswa hendaknya dibagi menjadi beberapa kelompok. Hal ini dilakukan agar siswa dapat bertukar catatan yang telah diperoleh kemudian mendiskusikan dengan anggota kelompok lainnya.

d) Analisis dan koreksi. 
Ada berbagai cara untuk menangani tahap ini. Pertama, setiap teks versi siswa bisa ditulis pada papan tulis. Kedua, teks bisa diperbanyak dan dibagi-bagikan kepada semua siswa. Ketiga, siswa bisa membandingkan versi mereka dengan teks asli, kalimat demi kalimat.

Sedangkan sintaks dalam pembelajaran dengan menggunakan strategi dictoglos, antara lain:

a) Langkah 1

Persiapkanlah sebuah teks bacaan sepanjang satu atau dua paragraf

b) Langkah 2

Bagilah siswa atas kelompok-kelompok. Setiap kelompok terdiri atas 3 atau 5 orang.

c) Langkah 3

Bacalah teks dengan kecepatan sedang. Instruksikan terlebih dahulu agar semua siswa menyimak teks yang dibacakan.

d) Langkah 4

Bacalah teks sekali lagi. Instruksikan agar semua siswa dalam kelompok mencatat kata-kata yang dapat mereka tangkap dari teks yang dibacakan.

e) Langkah 5

Semua kelompok merekonstruksi ulang teks yang dibacakan berdasarkan katakata atau penggalan kalimat yang mereka dapat dari hasil mencatat bahan simakan.

f) Langkah 6

Presentasi hasil kerja kelompok.

Keberadaan sejarah dalam ilmu pengetahuan sosial tidak dapat dilepaskan dari peranannya, baik sebagai peristiwa, sebagai kisah maupun sebagai ilmu pengetahuan. Sejarah sebagai peristiwa adalah kejadian, kenyataan, aktualitas, yang sebenarnya telah terjadi atau berlangsung pada waktu yang lampau (Ismaun: 2005). ${ }^{4}$

${ }^{4}$ Ismaun, Sejarah Sebagai IImu (Bandung Historia Press: 2005). 
Hal ini didukung oleh pernyataan (Waspodo : 2005), bahwa sejarah sebagai peristiwa, berarti suatu kejadian di masa lampau, sesuatu yang sudah terjadi, dan sekali jadi serta tidak bisa diulang. ${ }^{5}$

Dari pendapat para ahli tersebut dapat disimpulkan bahwa sejarah sebagai peristiwa dapat didefinisikan sebagai suatu kejadian nyata yang terjadi pada masa lampau, yang hanya terjadi sekali dan tidak dapat diulang serta peristiwa tersebut memiliki pengaruh yang besar pada masanya atau pada masa-masa selanjutnya. Peristiwa yang dipelajari dalam sejarah adalah peristiwa yang berkaitan dengan kehidupan manusia, baik sebagai individu maupun sebagai kelompok.

Salah satu kemampuan yang harus dimiliki oleh siswa sekolah dasar adalah kemampuan menceritakan kembali peristiwa sejarah. Kronologi sejarah berarti sesuai dengan urutan waktu kejadian dari peristiwa sejarah tersebut, sehingga tidak berlangsung secara loncat-loncat, walaupun demikian susunan kejadian berdasarkan urutan waktu tersebut harus tetap berkisinambungan dan menunjukan kualitas (sebab-akibat). Dalam hal ini diperlukan adanya pembelajaran kronologi, dimana pembelajaran ini sangat penting karena urutan peristiwa menjadi kunci pokok dalam memahami masa lampau dan masa sekarang.

Kemampuan menceritakan peristiwa sejarah di sekolah dasar bertujuan untuk menanamkan konsep pentingnya menghargai sejarah pada diri siswa. Dengan dikembangkannya kemampuan ini maka nantinya siswa akan dapat memahami peristiwa sejarah sekaligus dapat menerapkan nilai-nilai positif yang terkandung dalam kehidupan sehari-hari.

Strategi dictoglos merupakan strategi dalam pembelajaran menyimak. Strategi ini dirasa cocok dalam meningkatkan kemampuan menceritakan kembali peristiwa sejarah. Karena dalam pembelajaran mengenai peristiwa sejarah, siswa melakukan kegiatan menyimak cerita yang dibacakan guru. Maka dari itu strategi ini sangat cocok digunakan dalam pembelajaran sejarah khususnya mengenai peristiwa sejarah.

Dalam pembelajarannya, siswa mencatat hal-hal yang dirasa penting ketika menyimak peristiwa sejarah yang dibacakan oleh guru. Strategi ini memang dirancang khusus dalam pembelajaran menyimak agar guru tidak terlalu mendominasi pembelajaran dan siswa akan aktif dalam pembelajaran. Dengan demikian maka materi yang disampaikan guru dapat diterima dengan baik dan pada akhirnya tujuan pembelajaran juga akan dapat tercapai.

\footnotetext{
${ }^{5}$ Waspodo, Pengetahuan Dasar Ilmu-ilmu Sosial. (UNESA Surabaya:2005)hal:43
} 
Proses pembelajaran yang dilakukan adalah dengan cara menyimak cerita mengenai materi pembelajaran yang dibacakan oleh guru, kemudian siswa mencatat hal-hal yang dianggap penting misalkan tanggal-tanggal penting beserta peristiwa yang terjadi. Kemudian siswa berdiskusi secara berkelompok untuk merekonstruksi kembali cerita yang telah disimak bersumber dari catatan yang telah diperoleh ketika menyimak cerita yang dibacakan oleh guru. Kemudian tiap-tiap kelompok membacakan hasil rekonstruksi cerita dengan menggunakan kalimat sendiri. Dengan menggunakan strategi ini diharapkan siswa dapat lebih memahami peristiwa sejarah yang terjadi di Indonesia secara runtut dan juga tepat.

Dictoglos adalah suatu strategi yang dapat membantu siswa untuk menggunakan sumber daya mereka miliki dalam hal merekonstruksi teks. Strategi ini sangat cocok digunakan untuk menceritakan kembali teks yang telah disimak.

Penerapan strategi dictoglos dalam pembelajaran ips sangat cocok, karena dapat mempermudah siswa dalam memahami peristiwa sejarah yang bersumber dari cerita sejarah yang dibacakan oleh guru. Kompetensi dasar yang dirasa sesuai adalah KD 2.1 tentang mendeskripsikan perjuangan para tokoh pejuang pada masa penjajahan Belanda dan Jepang.

Dalam pelaksanaan pembelajaran dengan menggunakan strategi dictoglos, guru tetap menggunakan pembelajaran klasikal (ceramah, tanya jawab, atau diskusi dan tugas) dalam penyajian materi pelajaran. Tetapi pembelajaran klasikal tersebut dikembangkan atau diperkaya guru dengan strategi dictoglos sehingga dapat meningkatkan kemampuan siswa dalam hal menceritakan kembali peristiwa sejarah sekaligus tujuan pembelajaran yang diharapkan dapat tercapai.

Penelitian ini merupakan penelitian tindakan kelas dengan menggunakan metode deskriptif kualitatif. Prosedur pelaksanaannya mengikuti prinsip dasar tindakan kelas. Mengacu pada pandangan Kemmis dan Taggrat (1998) dalam Arikunto:2006 penelitian tindakan diawali dengan mengidentifikasi gagasan umum yang dispesifikasikan sesuai dengan tema penelitian. Spesifikasi gagasan tersebut selanjutnya digarap melalui empat tahap secara berdaur ulang, yaitu perencanaan, pelaksanaan tindakan dalam pembelajaran di kelas, pengamatan dan refleksi. Hal tersebut dilakukan sebagai rangkaian kegiatan pada siklus pertama. $^{6}$

\footnotetext{
${ }^{6}$ Arikunto. Prosedur Penelitian Suatu Pendekatan Praktik (Rineka Cipta: Jakarta). 2006. hal 97
} 
Berdasarkan hasil refleksi siklus pertama, dilakukan perbaikan tindakan pada siklus kedua. Peneliti bersama guru kelas menyusun rencana tindakan siklus kedua kemudian dilanjutkan dengan pelaksanaan tindakan dalam pembelajaran di kelas pada siklus kedua, pengamatan dan refleksi, begitu seterusnya hingga tujuan yang diinginkan tercapai yang merupakan unsur-unsur dalam penelitian PTK.

Subjek yang dikenai tindakan pada penelitian ini adalah siswa kelas V MI Ma'arif NU Sukolilo Kecamatan Sukodadi Kabupaten Lamongan tahun pelajaran 2019-2020 dengan jumlah siswa 27 orang yang terdiri dari 14 orang siswa perempuan dan 13 orang siswa lakilaki dengan rata-rata usia antara 10 sampai 12 tahun. Pemilihan subjek didasarkan pada materi menceritakan kembali peristiwa sejarah yang cocok diterapkan dengan menggunakan strategi dictoglos, sesuai untuk kelas V pada Kompetensi Dasar 2.1 Mendeskripsikan perjuangan para tokoh pejuang pada masa penjajahan Belanda dan Jepang.

Lokasi penelitian yaitu di MI Ma'arif NU Sukolilo Kecamatan Sukodadi Kabupaten Lamongan. Pemilihan lokasi didasarkan pada (1) Lokasi MI Ma'arif NU Sukolilo Kecamatan Sukodadi Kabupaten Lamongan mudah dijangkau oleh peneliti, (2) Guru Kelas V MI Ma'arif NU Sukolilo Kecamatan Sukodadi Kabupaten Lamongan siap berkolaborasi untuk melaksanakan penelitian tindakan kelas guna memperbaiki kualitas pembelajaran.

Dengan beberapa pertimbangan dan alasan, peneliti menentukan menggunakan waktu penelitian selama 2 bulan yaitu pada bulan September s.d Oktober. Waktu dari perencanaan sampai penulisan laporan hasil penelitian tersebut pada semester I Tahun pelajaran 20192020. Munculnya penelitian ini dikarenakan hasil ulangan harian siswa dengan materi peristiwa sejarah masih belum mencapai kompetensi nilai yang diharapkan.

Adapun prosedur pelaksanaan kegiatannya adalah sebagai berikut:

1) Tahap Perencanaan Tindakan

Berdasarkan rumusan masalah hasil observasi di lapangan, peneliti dan guru melakukan perencanaan tindakan dengan langkah sebagai berikut:

a) Menyusun rencana pembelajaran menceritakan kembali peristiwa sejarah dengan strategi dictoglos

b) Merencanakan langkah-langkah kegiatan pembelajaran dengan strategi dictoglos

c) Merencanakan alat evaluasi baik evaluasi proses maupun evaluasi hasil pembelajaran bahasa dengan strategi dictoglos

d) Menyusun pedoman pengamatan tentang pelaksanaan pembelajaran menceritakan kembali cerita anak dengan strategi dictoglos 
e) Merumuskan indikator ketercapaian tujuan penelitian, yaitu jika siswa (1) dapat menceritakan kembali peristiwa sejarah secara runtut, (2) dapat menceritakan peristiwa sejarah dengan runtut dan tepat dengan menggunakan kalimat sendiri.

2) Tahap Pelaksanaan Tindakan

Tahap ini merupakan penerapan rancangan yang telah dibuat. Pelaksanaan tindakan berupa pelaksanaan pembelajaran IPS dengan strategi dictoglos di kelas V MI Ma'arif NU Sukolilo Kecamatan Sukodadi Kabupaten Lamongan. Pelaksanaannya dilakukan peneliti bersama dengan guru kelas. Pelaksanaan tindakan direncanakan dengan rangkaian siklus-siklus secara berulang. Siklus I dilakukan 1 x pertemuan, siklus II dilakukan 1 x pertemuan dan jika semua indikator sudah tercapai maka siklus akan diakhiri.

Kegiatan pembelajaran yang dilakukan pada setiap siklus dapat digambarkan dengan langkah-langkah sebagai berikut: (a) Guru mengadakan apersepsi sebagai upaya pembangkitan skemata siswa berkaitan dengan apa saja yang mereka ketahui mengenai peristiwa sejarah di Indonesia. (b) Guru memberi instruksi kepada siswa untuk mencatat hal-hal penting saat menyimak cerita yang dibacakan oleh guru; (c) Guru membacakan cerita mengenai peristiwa sejarah di Indonesia, yaitu peristiwa perjuangan para tokoh pejuang pada masa penjajahan Belanda dan Jepang; (d) Guru mengelompokkan siswa sebanyak 3 atau 5 orang.; (e) Guru memberi instruksi pada siswa untuk merekonstruksi hal-hal penting yang didapat dari kegiatan menyimak cerita secara berkelompok; (f) Guru memberi kesempatan setiap kelompok maju ke depan untuk menampilkan hasil rekonstruksi peristiwa sejarah berdasarkan catatan yang didapat; (g) Guru memberikan dan tanggapan pembenaran pada siswa bila masih ada kekeliruan dan memberikan pujian bagi siswanya; (h) Guru menyimpulkan hasil pembelajaran dan siswa mencatat di buku catatan masing-masing.

Pada Siklus I selama 2 kali pertemuan siswa masih dibiasakan dengan metode tersebut, sedangkan pada Siklus II siswa akan lebih dimantapkan dalam menggunakan metode ini.

3) Tahap Observasi

Tahap ini dilakukan oleh peneliti bersama dengan guru kelas. Pada tahap ini peneliti dan guru kelas mengamati secara intensif pelaksanaan pembelajaran 
menceritakan kembali peristiwa sejarah dengan menggunakan strategi dictoglos di kelas V MI Ma'arif NU Sukolilo Kecamatan Sukodadi Kabupaten Lamongan Hal yang dilakukan peneliti saat pengamatan, antara lain:

a) Mengamati dan mencatat semua gejala yang muncul baik yang mendukung atau menghambat proses pembelajaran.

b) Mencatat hasil observasi dalam lembar observasi berupa catatan check list.

c) Mengelompokkan gejala yang muncul, gejala saat kegiatan awal pembelajaran, kegiatan inti pembelajaran dan kegiatan akhir pembelajaran.

d) Dari pengelompokkan data tersebut diseleksi untuk dijadikan data penelitian, data yang relevan dengan lingkup penelitian dimasukkan dalam data yang nanti akan dianalisis, sedangkan data yang tidak relevan dibuang.

4) Tahap Refleksi / Evaluasi

Berdasarkan analisis data tersebut, kemudian dilakukan refleksi. Apabila pada siklus itu ada hal-hal yang dianggap kurang dan perlu diperbaiki maka dilaksanakan tindakan pada siklus berikutnya. Misal kekurangan pada siklus I digunakan dasar untuk perbaikan pada siklus II dan seterusnya.

Hal-hal yang dilakukan saat refleksi, antara lain:

a) Mengidentifikasi kelebihan dan kekurangan yang ditemukan saat siklus 1 dan juga mengidentifikasi tindakan apa saja yang belum dilakukan oleh guru selama proses pembelajaran.

b) Mencatat apa saja hal-hal yang perlu perbaikan dan berdiskusi dengan guru kelas $\mathrm{V}$ untuk memperbaiki cara pengajaran yang masih dianggap kurang.

c) Apabila dalam siklus ditemukan hal-hal yang kurang dan perbaikan, maka perbaikan akan dilakukan saat siklus berikutnya. Kekurangan yang ditemukan di siklus 1 akan dijadikan dasar perbaikan di siklus 2 dan seterusnya.

Data yang diperlukan dalam penelitian ini, adalah Hasil pengamatan tentang aktivitas guru dalam mengajar dan aktivitas siswa dalam materi menceritakan kembali peristiwa sejarah menggunakan strategi dictoglos. Hasil pekerjaan siswa untuk mengetahui kemampuan menceritakan kembali peristiwa sejarah mencakup kemampuan menceritakan cerita secara runtut dan tepat dengan menggunakan kalimat sendiri.

Adapun teknik pengumpulan data dilakukan dengan: 
a) Observasi dilakukan untuk mengamati latar kelas, tempat berlangsungnya

b) pembelajaran. Aktivitas yang diamati adalah aktivitas pembelajaran menceritakan kembali peristiwa sejarah dimulai dari tahap menyimak cerita, menulis kata-kata yang dianggap penting dan merekonstruksi kata-kata penting yang ditulis menjadi sebuah rangkaian cerita. Pengamatan dilakukan dalam setiap siklus tindakan.

c) Catatan lapangan dilakukan dalam kaitannya mendeskripsikan paparan tentang latar kelas pada waktu berlangsungnya pembelajaran. Catatan berkaitan dengan partisipasi siswa pada saat proses pembelajaran menceritakan kembali peristiwa sejarah dengan strategi dictoglos.

d) Wawancara dilakukan terhadap guru kelas dan siswa untuk mendapatkan informasi tentang pembelajaran menceritakan kembali peristiwa sejarah dengan strategi dictoglos. Informasi tersebut berkaitan dengan perilaku belajar dan proses berpikir siswa selama kegiatan belajar mengajar berlangsung.

e) Dokumentasi berupa hasil karangan siswa mulai dari tahap menyimak cerita mengenai peristiwa sejarah sampai menceritakan kembali peristiwa sejarah yang telah dibacakan oleh guru. Selain itu dokumentasi juga berupa bentuk gambar foto aktivitas siswa ketika mengikuti pembelajaran yang telah dibuat oleh guru bersama peneliti.

Data penelitian ini dianalisis dengan menggunakan teknik deskriptif kualitatif. Proses analisis dimulai dengan menelaah data secara keseluruhan, melakukan reduksi data, menyusunnya dalam satuan-satuan dan mengkategorikannya. Hal itu dilakukan dengan mengacu pada teknik analisis data model mengalir yang dikemukakan oleh Milles dan Huberman (1992:18) dalam Arikunto:2006 data yang terkumpul dari penelitian ini dianalisis dari penyajian data dan penarikan kesimpulan. ${ }^{7}$

${ }^{7}$ Arikunto. Prosedur Penelitian Suatu Pendekatan Praktik (Rineka Cipta: Jakarta). 2006. hal 97 
Proses analisis dilakukan sejak kegiatan menyimak sampai kegiatan menceritakan kembali peristiwa sejarah dengan menggunakan strategi dictoglos pada siswa kelas V MI Ma'arif NU Sukolilo Kecamatan Sukodadi Kabupaten Lamongan. Hal tersebut dilakukan dari siklus I sampai mendapatkan hasil yang diharapkan.

\section{Daftar Pustaka}

Arikunto, Suharsimi. 2006. Prosedur Penelitian Suatu Pendekatan Praktik. Jakarta: Rineka Cipta.

Baharuddin \& Wahyuni, Esa Nur. 2007. Teori Belajar \& Pembelajaran. Jogjakarta: Ar-Ruzz Media

Ismau. Sejarah Sebagai Ilmu. 2005. Bandung Historia Press.

Kochhar, S.K. 2008. Pembelajaran Sejarah. Jakarta: Grasindo

Mulyati, Strategi Belajar Mengajar IPS. 200. Raja Grafindo Persada.

Sardiyo, dkk. 2008. Pendidikan IPS di SD. Jakarta: Universitas Terbuka

Subroto, Waspodo Tjipto \& Suhanadji. 2005. Pengetahuan Dasar Ilmu-ilmu Sosial. Surabaya

Sumaatmadja, Materi Konsep Dasar IPS. 2008. Karunika Universitas Terbuka. 